Please note, this is the accepted version of the article:

Tulumello S., Cotella G., Othengrafen F., "Spatial Planning and Territorial Governance in Southern Europe between Economic Crisis and Austerity Policies", https://doi.org/10.1080/13563475.2019.1701422.

The Version of Record of this manuscript has been published and is available in International Planning Studies 08/12/2019, DOI: 10.1080/13563475.2019.1701422. 
Spatial Planning and Territorial Governance in Southern Europe between Economic

\section{Crisis and Austerity Policies}

Simone Tulumello (corresponding author)

Universidade de Lisboa, Instituto de Ciências Sociais

Av. Prof A. De Bettencourt 9, 1600-189, Lisbon, Portugal

simone.tulumello@ics.ulisboa.pt

$+351217804700$

https://orcid.org/0000-0002-6660-3432

Giancarlo Cotella

Politecnico di Torino, Interuniversity Department of Regional and Urban Studies and Planning

Viale Mattioli 39, 10125, Torino, Italy

giancarlo.cotella@polito.it

+393384673925

https://orcid.org/0000-0001-8445-412X

Frank Othengrafen

TU Dortmund, School for Spatial Planning

44221 Dortmund, Germany

frank.othengrafen@tu-dortmund.de

+492317552259

https://orcid.org/0000-0001-6348-4485

\section{Acknowledgements and funding}

We are grateful to two anonymous reviewers for constructive critique and detailed suggestions, which helped us streamline and strengthen our arguments. Simone Tulumello is funded by the Fundação para a Ciência e Tecnologia (DL57/2016/CP1441/CT0007).

\section{Disclosure statement}

The authors have no potential conflicts of interest with respect to the research, authorship, and/or publication of this article. 
Keywords: policy change; comparative planning studies; austerity politics; planning systems; planning policy.

\section{Abstract}

This article examines how spatial planning systems have changed in Portugal, Spain, Italy and Greece in times of economic recession and austerity politics, in amid pressures of external actors and local conditions and traditions. We analyse the round of reforms of spatial planning and territorial governance implemented by national governments under pressures by European institutions, as well as local responses to them. On the one hand, we highlight how European institutions have used the conditionalities attached to bailout packages and other instrument of pressure to frame what can be considered an implicit Southern European spatial planning policy developed by the European Union. On the other, we suggest that Southern European planning amid crisis and austerity should be understood, together, as field that problematizes the idea of Europeanization of planning; a space used as 'prototype' for new rounds of neoliberalization; and a political space that continuously develops through topdown/bottom-up dialectic conflicts.

\section{Introduction}

Southern European spatial planning systems and territorial governance have been under pressure since the beginning of the global economic crisis and were blamed for their incapacity of preventing - and their role in boosting - real estate and construction bubbles which, inter alia, caused or intensified the crisis in Portugal, Spain, Italy and Greece (Cotella 
et al. 2016; Ponzini 2016). As a consequence, national governments have, in times of austerity pushed by European institutions, launched a set of reforms that changed Southern European spatial planning systems and territorial governance in depth, impacting over a field that had gone through significant processes of change since, at least, the 1990s. This set of reforms, as we shall see, had quite homogeneous rationales, irrespective of the different crisis trajectories and policy traditions of the four countries.

As such, Southern European spatial planning and territorial governance constitute a unique space to understand the intersection between fast changes in times of crisis and austerity, and long trends of persistence/change. However, even if there exists a rich literature on causes and effects of crisis and austerity in Southern Europe (see, among others, Hadjimichalis 2011; the special issue of City 18[4/5], 2014; Knieling and Othengrafen 2016; Janin Rivolin 2017), much less has been written about the impacts of austerity politics on spatial planning systems and territorial governance, with few exceptions about specific topics or geographic contexts (e.g. Ponzini, 2016; Tulumello 2016). To shed more light on the interrelations between crisis, austerity regimes, spatial planning systems and territorial governance, our contribution to this special issue revolves around two research questions. How have crisis and austerity impacted spatial planning and territorial governance in Southern Europe? And, how are current reforms of spatial planning and territorial governance in these countries influenced by the demands of European Union (EU) institutions and austerity politics?

By answering these questions, the aim of this article is to reflect on the significance of rapid processes of change - amid pressures of external actors, such as international creditors for the present and future of spatial planning principles, strategies and instruments. In line with recent critiques of the dominance of taxonomical approaches in existing comparative planning studies (see Tulumello et al. 2018), we expect to enrich the understanding of policy 
change by focusing on the way spatial planning systems and territorial governance are shaped by a mix of internal conditions and cultures, and external pressures.

Our empirical reconstruction of changes in national spatial planning systems and territorial governance policies is based on the analysis of EU policy documents on financial bailouts, and of national policy or statutory documents that came into force during the austerity period in Portugal, Spain, Italy and Greece. In the case of Greece, we further carried out four interviews in 2016 and 2017 with senior planners to overcome the language barrier and to complement our understanding of the processes. Finally, we compared and analysed data collected in parallel researches (e.g. Knieling and Othengrafen 2016; Tulumello 2016; Nadin et al. 2018) to gain a deeper understanding on the trajectories of change in domestic territorial governance and spatial planning systems and practices.

Our argument is structured in four steps. First, we review the explanations about the causes of economic crisis in Southern Europe to highlight the complexity of national trajectories; and then focus on the role of territorial development and planning in generating some preconditions for crisis. Second, we focus on the dominant anti-crisis response, that is, austerity, reviewing discussions about the role of European institutions in pushing for it and its impacts on territorial development and planning. Third, we call for the need of a systematic exploration of policy change in spatial planning and territorial governance amid crisis and austerity in Southern Europe; and suggest that the concept of Europeanization offers a theoretical framework for conceptualizing the mentioned change. Fourth, we analyse the reforms promoted during the crisis and amid austerity: new spatial planning laws with the purpose of re-launching real estate and construction; territorial governance reforms in the name of expenditures' rationalization; and local policymaking in conflict with top-down austerity. In conclusion, we set out a tentative theorization of ongoing processes. On the one hand, we highlight how the analysed reforms are framed within a rather coherent 'Southern 
European EU spatial planning policy' or, paraphrasing Doling's discussion in the field of housing (2006), a EU spatial planning policy 'by stealth'. On the other hand, we question whether Southern European spatial planning should be understood as a challenging field for Europeanization due to its traditions and path dependencies; a space used as 'prototype' for testing policy solutions; or a political space that continuously develops through topdown/bottom-up dialectic conflicts.

Economic crisis in Southern Europe - and the role of spatial planning and territorial governance

The recent economic crisis that affected Southern European countries was considered to be caused by a combination of weak economic performance with institutional or political mismatches (Chuliá, Guillen and Santolino 2016, 19). Still, there are important differences in the trajectories of Portugal, Spain, Italy and Greece (see; Knieling and Othengrafen 2016; Perez and Matsaganis 2017; Manasse and Katsikas 2018). In Portugal and Greece, an important role has been played by economic models based on sectors with low productivity and high employment - and hence low wages, large proportion of unskilled workers and stagnant productivity (Reis and Rodrigues 2011; Labrianidis and Vogiatzis 2013; Carneiro, Portugal and Varejão 2013). In Greece this caused that wages in the public sector had been increased on basis of political decisions to stimulate the (local) domestic demand and economic growth. In absence of a concurrent productivity growth, this has been dependent on borrowing (Tsakalotos 2011); and the fall of interest rates caused by the participation of Greece in the Eurozone further pushed in this direction. According to Serroas and colleagues (2016, 120), 'this inevitably resulted in a major imbalance between state expenses and 
financial ability as well as borrowing and repayment ability.' When interest rates started growing again as a result of the global financial crisis, this gave rise to massive budget deficit, resulting in a simultaneous inability to attract further external finance (idem, 121). The case of Italy, by far the largest economy in Southern Europe, however suggests that things are more complex. Italy has been suffering of 'low growth, old age, low productivity and institutional sclerosis' (Blyth 2013, 68); but also of the long term decline of the construction and real estate sector that had been crucial for the growth of the country in the post-World-War-Two age (cf. Salzano 1998).

The latest point reminds us that public expenditure is just one part of the picture and that urbanization economies played an important role as well. On the one hand, urbanization has been one of the drivers for economic development; but, on the other hand, it has been accomplished to a large extent through loans and debts that have contributed to the speculative bubble of the real estate markets and the eruption of the crisis, first in the USA, then in Southern European cities. Critical scholars have thus suggested that the post-2007 crisis was in fact an urbanization crisis, growing out of speculative investments relating to the built environment and to the redistribution of real income embedded in the operations of the capitalist city (García 2010; Harvey 2012; Seixas et al. 2016). This was particularly evident in Spain, a bank dominated economy (Akin et al. 2014, 3), where the growth model was also highly dependent on domestic demand, but more specifically on construction and property development activities (García 2010; Romero, Melo and Brandis 2016, 73). ${ }^{1}$ Following Carballo-Cruz $(2011,309)$, 'the disproportionate growth in the real estate sector, coupled with the expansion of credit needed to finance it, is at the basis of economic imbalances.' The

\footnotetext{
${ }^{1}$ The excessive dependence of the economy on the construction sector is visible in Greece as well, and this is also a characteristic of the Italian economy since the second half of the 1900.
} 
massive credits granted to construction and property development activities caused an exposure of the banking industry on housing (idem; Chuliá, Guillen and Santolino 2016), meaning that banks provided low-interest mortgages to house purchasers (and brought debts to households and companies). Household mortgages were at the peak $65 \%$ of the Spanish GDP and loans to real estate developers and construction firms accounted for another $45 \%$ of the GDP (Akin et al. 2014, 3-4). ${ }^{2}$ In Portugal, where in the pre-crisis period public debt was extremely low, the massive private indebtedness - that was transferred to the public sector by bank bailouts in the aftermath of the financial crisis - was primarily due to households' mortgages, and the real estate and construction sector (Santos, Teles and Serra. 2014).

This brief summary of the trajectories of Southern European countries shows, on the one hand, the complex and variegated nature of the economic crisis; and, on the other hand, the centrality of territorial development in the creation of pre-conditions for the crisis. If urbanization economies were crucial in triggering the crisis, spatial planning and territorial governance had clearly played a role. In Spain, for example, where urban development was mainly driven by the construction industry, 'regulatory planning is rejected, metropolitan forms of governing the territory are absent, public-private partnerships are privileged, [and] the role of the public sphere is reduced' (Romero, Melo and Brandis 2016, 74). Urban projects and mega events are favored by politicians and the construction industry, supported by large public sector investments in infrastructures of doubtful profitability, and implemented through ad hoc partial plans and integrated action plans (idem, 75-79).

\footnotetext{
${ }^{2}$ In Greece, the residue of housing loans increased dramatically from 17 billion Euro in 2000 to 93.7 billion Euro in 2007 (Triantafyllopoulos and Kanyla 2010).
} 
The traditional explanation of these problems has been found in the dominance of 'conformative approaches' to spatial planning in Southern European countries (Janin Rivolin 2008; Knieling et al. 2016). Conformative systems, characterised by rigid regulations and zoning codes, have been problematic in terms of 'public value-capturing' over time due to the attribution of building rights through local plans (Gielen and Tasan-Kok 2010, Janin Rivolin 2017). In turn, this tended to increase the rigidity of planning tools, with any attempt to reform them that implied the assignation of additional rights. Such situation, together with the absence of comprehensive urban (and national) strategies as well as of local programming capacity (Cotella and Janin Rivolin 2011, 43; Lingua and Servillo 2014, 128) and the delay that some countries such as Portugal or Greece experienced in the development of urban master plans (Oliveira and Breda-Vázquez 2011, 66-67), led to intense construction activities. This situation has been amplified over time by national cuts over municipal budgets, which forced municipal governments to sell public land and encourage new developments to benefit from building taxes.

\section{Austerity in Southern Europe and its territorial effects}

In face of the economic crisis, various anti-crisis policies have been introduced. However, irrespective of the peculiarities of national contexts, for the national governments of Portugal, Spain, Italy and Greece, supported by either centre-right parties or large coalitions, austerity has been the only game in town - at least until 2015, when in Greece and Portugal new governments supported by centre-left and left-wing parties have partially broken with austerity. Austerity is commonly associated to policies conducted to reduce budget deficits using combinations of spending cuts and tax rises (see Donald et al. 2014; Marti-Costa and 
Tomàs 2017). The (apparent) paradox between different trajectories and similar responses has sparked discussion (see below), especially about the extent to which political reforms in Southern Europe, in areas such as labour market, pensions and economic governance, have been introduced from the top by the EU. With regards to economic governance, there seems to be agreement on the fact that the European Commission has strengthened its role (Bauer and Becker 2014). Especially in the countries undergoing external bailouts, reforms, included in memoranda of understanding and monitored during and after the bailout period, have been required by creditors including the European Central Bank and European Commission (Clauwert and Schömann 2012). This is particularly observable in Greece, while in Portugal things have been made more complex by the role of the Constitutional Court in vetoing some reforms and budget cuts (Magone 2014). Also in Italy, which did not undergo a bailout, the EU has pushed structural reforms using an 'implicit conditionality' (Sacchi 2015). 'Actual or potential access to EU financial support - carried out through purchase of Italy's bonds to alleviate market tensions on its debt - was the implicit carrot. The threat of having to enter formalized, explicit conditional lending programmes [...] was the implicit stick. Market discipline was the operating mechanism that made implicit conditionality effective' (idem, $78) .^{3}$

\footnotetext{
${ }^{3}$ At the same time, however, some national governments and (especially centre-right) political parties may have exploited the crisis as an opportunity. According to Hopkin and Dubin (2014), in Italy and Spain political parties have tried to strengthen their electoral position by delivering policies to favour their key constituents. Moury and Standring (2017) suggest that in Portugal, while the bailout has limited the executive autonomy, it also made them stronger in relation to domestic actors, giving strong arguments to deliver reforms allegedly necessary to save the country. Indeed, in 2015, toward the end of the mandate during which the deepest austerity measures had been implemented, the former Portuguese Ministry of Health proudly claimed: 'fomos para alem da Troika',
} 
Austerity policies also deeply impact territorial development, by intensifying uneven socio-spatial developments (Peck 2012, 633). As cities under austerity regimes become more reliant on their own resources, wealthier cities perform better than less developed cities or regions. Indeed, after a period of convergence and reduction of regional and national polarization, economic polarization in Southern European states - particularly within member states - increased again since the 2007 financial crisis (Pinho, Andrade and Pinho 2010; Hadjimichalis 2011; Chuliá, Guillen and Santolino 2016). The intensification of uneven development led by austerity politics brings with it increased difficulties to deliver policy solutions and provide services at the local level (Silva and Bucek 2014; Marti-Costa and Tomàs 2017, 2109). Austerity - be it directly pushed by memoranda of understanding in countries under bailout or chosen by national governments - led to the dismantling of the already weak welfare state (Cotella et al. 2016; Arampatzi 2017). Under austerity, local authorities are forced to become more entrepreneurial in order to promote economic development, thus paving the way to large-scale privatizations of municipal assets to reduce indebtedness (Wollmann 2014, 68; Hadjimichalis 2014). ${ }^{4}$

This entrepreneurial orientation becomes also visible when considering spatial planning and territorial governance. Getimis, Reimer and Blotevogel (2014, 298), for example, conclude that spatial planning in times of the crisis has moved "towards "market-led" planning, in order to facilitate private investments and to overcome planning burdens through

\footnotetext{
'we went beyond the Troika' (troika is a term ironically used to refer to the three lenders International Monetary Fund, European Commission and European Central Bank).

${ }^{4}$ In some Spanish cities such as Madrid or Valencia this development has been going on for quite some time: as shown above, an entrepreneurial approach to spatial planning and missing regulations have been among the driving forces of the economic crisis.
} 
outsourcing specific planning services.' At the same time, this also included the 'weakening of strict environmental and planning regulations and "bypassing" of planning burdens through specific planning regulations' (idem, ibidem).

\section{Conceptualising spatial planning policy change under crisis and austerity}

The aforementioned general considerations calls for a systematic exploration, and possibly for a theorization, of policy change in spatial planning and territorial governance in Southern Europe during the years of crisis and austerity - the objective to which we shall turn now. Acknowledging the role played by European institutions in pushing austerity as the dominant answer to economic crisis (see previous section), our systematic exploration includes an analysis of the role of said institutions. And it is by focusing on vertical relationships among levels of government that we shall take some preliminary steps toward a theorization of recent policy changes in this area.

The concept of Europeanization offers a particularly useful lens in this respect (Olsen 2002; Featherstone and Radaelli 2003; Radaelli 2004). Indeed, the EU has long been involved in triggering policy change in spatial planning and territorial governance (Giannakorou 2005; Janin Rivolin and Faludi 2005; Stead and Cotella 2011). Despite never having been endowed with formal competence on spatial planning by Member States, European institutions have influenced domestic spatial planning and territorial governance by setting common goals for the development of the European territories, funding collaborative research projects on spatial development and research through the European Spatial Planning Observation Network (ESPON) since 2001, and fostering the cooperation and transfer of best practices (Radaelli 
2002; ESPON and Politecnico di Torino 2014, Janin Rivolin and Cotella, 2013; Cotella, Janin Rivolin and Santangelo 2015).

Building a conceptual framework for exploring the influence of the EU over domestic spatial planning and territorial governance has been the purview of the field of comparative studies of planning systems (Böhme and Waterhout 2008; Cotella and Janin Rivolin 2015; Nadin et al. 2018), which has been inspired by the publication of the EU Compendium of Spatial Planning Systems and Policies in 1997 (CEC 1997). In particular, the Compendium included Mediterranean countries into the so-called 'urbanism tradition', with a strong architectural focus, including urban design, townscape and building control, and where various laws and regulations exist without a coherent system or general public support (idem, 37; see also Lingua and Servillo 2014, 128). In line with this conceptualization, Southern European spatial planning systems have often been referred to as 'immature' (CEC 1997; Nadin and Stead 2013), and hence in need to converge toward 'mature' systems, that is Central and North-western, 'more efficient' and 'productive' systems. Indeed, the last few decades have seen significant changes in Southern European spatial planning, which has departed from the urbanism paradigm, undergoing diversification, progressively complementing land-use regulation with a number of innovative elements often resulting from the social experience of planning practice (Janin Rivolin and Faludi 2005; Governa and Salone 2005). Some observers therefore termed the late 1990s and the 2000s as the years of the Europeanization of the Italian (Cotella and Janin Rivolin 2011) and Portuguese (Oliveira and Breda-Vázquez, 2011) planning systems; and significant impacts have been also found in Greece (Giannakorou 2005) and Spain (Farinos Dasí, González and Madariaga 2005). And yet, the Europeanization did not prevent those spatial planning systems to be complicit in the explosion of the economic crisis, as we have seen. Though the exploration of the specific relations of cause and effects between the transformations dubbed as Europeanization and the 
burst of the crisis is outside the scope of this paper, this brief discussion suggests the need for a more context-specific and nuanced understanding of processes of policy change; and for questioning the role played by European institutions in the process.

We shall do this by borrowing an idea developed by Doling (2006) with particular reference to the field of housing. Doling has suggested that the EU has developed a housing policy 'by stealth', by means of achieving specific outcomes through regulations and decisions in other areas - for instance, impeding to use of Structural Funds for housing programmes or using financial deregulation as a way to favour access to credit and hence homeownership. By analogy, it is possible to hypothesize that the EU may have fostered a sort of spatial planning policy 'by stealth' in Southern Europe in times of crisis and austerity - and we shall verify this hypothesis in the following chapters. ${ }^{5}$

\section{Spatial planning and territorial governance under austerity: the EU, national reforms and local change}

Be they pushed by external creditors, be they willing to go beyond creditors' requests, or be they moved by political opportunity, Southern European policymakers have been

\footnotetext{
${ }^{5}$ It is important to remind that, also in this area, governments may have exploited the crisis to implement policies they wanted to implement in the first place, as this excerpt from an interview with a Portuguese Secretary of State suggests (Moury and Standring 2017, 10): 'in urban renewal, the Memorandum includes a rapid eviction process that takes place out of the courts; this is strongly contested by lawyers and the judicial professions because they make money from the processes and the lengthy proceedings. It was included in the Memorandum to give it the force of an agreement with the Troika and so something that had to be done.' However, this aspect will not be analysed in more detail as it is not presenting our main research focus.
} 
extremely active during the years of the crisis. Many reforms have been passed in the name of increasing 'efficiency of public administration', cutting 'red tape', fostering 'competiveness' (hence economic rebound and job creation) and increasing 'transparency'. ${ }^{6}$ To understand the impacts of austerity on spatial planning systems this section will, first, analyse the reforms of spatial planning and the introduction of new laws on the matter; second, focus on territorial governance reforms; and, third, briefly present the different paths emerged at the local scale.

\section{New spatial planning laws}

In 2014, general laws on spatial planning and land use regulations were passed in Portugal (Law 31/2014 about 'Guidelines for public policy about land, regional and urban planning' ${ }^{7}$ and Greece (Law 4269/2014 about 'Spatial and urban planning') ${ }^{8}$ at the explicit request of conditionalities agreed with external creditors. Though the first memorandum of understanding signed by Portugal did not make reference to spatial planning, requirements in the fields of transport, services and housing pointed to the simplification of procedures for spatial development (EC 2011b). ${ }^{9}$ The fifth review of the memorandum, then, explicitly

\footnotetext{
${ }^{6}$ Terms pinpointing the memoranda of understanding signed by Portugal (2011) and Greece (2011, 2012 and 2015).

${ }^{7}$ Accompanied by the New Juridical Regime of Territorial Management Instruments (Decree-Law 80/2015) and the New Regime of Classification, Reclassification and Qualification of Land (Regulatory Decree 15/2015).

${ }^{8}$ Complemented by special regimes to ease the privatization of public real estate (Law 3986/2011) and strategic investments (Law 3894/2010, amended by Law 4146/2013).

${ }^{9}$ Requests to privatize part of the rail system (EC 2011b, 85), abolish authorizations/licensing for the wholesale and retail sector (idem, 87), liberalize the rental market (idem, ibidem), simplify the rules for renovation,
} 
requested to 'review the legal regimes at all levels of Government in the area of territorial planning, in order to increase and facilitate the establishment of investors while at the same time limiting urban sprawl' (EC 2012a, 78). It is worth noting that the page about 'environment and territory planning' of the memorandum is under the section 'licensing environment' and that the requested reforms aim to align spatial planning with the Industrial Licensing regime. This may appear as a strategy to bypass the fact that the EU has not formal competence over spatial planning.

In line with the memorandum, the national government stressed the intention to make planning more 'flexible' and strengthen the 'strategic' (i.e., non-statutory) role of municipal masterplans (Governo de Portugal 2013). In the new legislation, only two land uses exist, urban and rural - all 'urban' land can potentially be urbanized. A combined effect of the Law 31/2014 and Decree-Law 80/2015 is the downgrading of sectoral, regional and national planning instruments promoted by the national government to 'programmes' without mandatory power over private actors (Oliveira, 2015) - the rationale being the simplification for investors, who shall find all rules within the municipal masterplan (cf. Governo de Portugal 2013). The downgrading of supra-local plans is in explicit contrast with decades of efforts for improving regional and national coordination of planning (cf. Campos and Ferrão 2015).

Also in the case of Greece, the spatial planning reform was requested by the creditors. The memorandum of understanding for the first bailout requests the creation of a land registry (EC 2010, 91) - also in this case, the provisions are under a different area, 'business environment'. (idem, 88). 
The fourth review of the first adjustment programme called for the need to operationalize spatial planning and land use frameworks (EC 2011a, 42-43), while the second adjustment programme explicitly required reforms in this field. The 2012 memorandum required, among 'growth-enhancing structural reforms' in the business environment section, to revise the regional spatial plans 'to make them compatible with the sectoral plans on industry, tourism, aquaculture and renewable energy', and to 'simplify and reduce time needed for town planning processes' (EC 2012c, 154). A new planning law was soon introduced (Law 4269/14), giving birth to Special Spatial Plans that shall facilitate the development of strategic public projects and private investments. All in all, procedures for development were simplified by: allowing 'covering of public and urban green spaces with new uses', 'casespecific overpassing of restrictive provisions in residential areas' and 'abolition of protective provisions at the local level'; 'promoting tourism uses without planning, within all residential areas'; and introducing 'post hoc many intransparent amendments to planning acts' (WWF 2014a, 5-6). The inclusion of the law's full implementation among the key requirements of the third financial assistance programme of $2015^{10}$ confirms that it was fully in line with creditors' requirements.

In Italy, in absence of explicit European requests, a quasi-reform of spatial planning was passed. The Decree-Law 133/2014 (about 'Urgent measures about launching of construction works, building of public works, digitalization, bureaucratic simplification, hydrogeological instability, and recovery of production activity') is not a comprehensive planning law, ${ }^{11}$ but a

10 Available at https://ec.europa.eu/info/sites/info/files/01_mou_20150811_en1.pdf (accessed 30 November 2019).

${ }^{11}$ In Italy, spatial planning is a competence shared with regional governments. Regions develop their own spatial planning laws within the frame of the national framework law 
set of regulations that allow to act in derogation to statutory planning and speed up the privatisation of public real estate. The 'urgency', evident in the decision to use a decree-law (which, in Italy should be used for urgent legislation only), was that of relaunching the economy, by "unjamming, ${ }^{12}$ the red-tape that public discourse traditionally associates to spatial planning in Italy. ${ }^{13}$

Spain was the only country not to pass spatial planning reforms at the national level, having most competences in this field located at the regional level (comunidades autonomas). ${ }^{14}$ All in all, the national legislation had already made planning laws quite 'efficient' and investor-friendly. A 1998 reform (Land Use Law 6/1998) increased flexibility of land uses and building controls, at the same time reducing administrative controls (Cladera and Burns 2000). After the burst of the real estate bubble, a new reform (Land Use Law 8/2007) tried to introduce some restrictions in the capacity of municipalities to create developable land, still falling short of having significant effects (Mora et al. 2011). In short, and despite the mentioned regional differences, the core object of Spanish spatial planning has long been 'creating' developable land (see also Vives and Rullan 2014). ${ }^{15}$ When providing

\footnotetext{
${ }^{12}$ The law was dubbed Sblocca Italia, Unjam Italy.

${ }^{13}$ Italian planning has historically been considered a restrain to economic growth in a country where real estate and construction were among the engines of economic growth since the post-WWII boom (Scattoni and Falco 2011). With more emphasis since the 1980s, the affirmation of liberalist politics was mirrored by discourses about planning regulations as 'big and small laces' (lacci e lacciuoli) that allegedly tie economic development (cf. Salzano 1998).

${ }^{14}$ In 1998, a decision by the Supreme Court reverted the attempts to harmonize planning and land use regulation at the national level (see Rullan 1999).

${ }^{15}$ The case of the municipal masterplan of Madrid is quite telling. Approved in 1997, the plan has been declared null by the High Court of Justice of Madrid in 2003 because of the missing justification for the transformation of
} 
financial assistance to the Spanish financial sector, the European Commission was aware of the central role of speculation and housing bubble in the generation of the crisis, but no conditionality clauses were included to regulate the sector and prevent further bubbles to generate (EC 2012b).

\section{Territorial governance reforms}

Together with spatial planning reforms, we can observe deep reforms of the territorial multilevel organization of public governance. We shall see how administrative layers were grouped and reshuffled in the name of simplification, increased efficiency and expenditure cuts. Also in this field, there seems to exist a coherent 'European hand', which guided national governments' action. A caveat is necessary. The discourse surrounding recent reforms rests in line with the long path of decentralization of countries that went out, at different stages (Italy in 1943, Portugal and Greece in 1974, Spain in 1976), from long centralizing dictatorships. As such, those reforms should be comprehended in line with long claims of 'delay' with regard to innovation of territorial management when compared to Western European experiences (see, e.g., Seixas and Albet 2012).

Administrative reform was included in the memorandum of understanding in Portugal (EC 2011b, 48). Law 22/2012 consolidated the sub-municipal level of parishes (freguesias),

areas previously protected into developable ones. Further revisions of the plan, which kept the lands developable while trying to make the planning process more 'flexible' (Vitoria 2013, 239), have been declared null again in 2008, 2012 and 2015, while a new revision had been launched in 2014, but was abandoned because of the change of government in 2015. For a period of almost 20 years characterized by governmental continuity, Madrid has not had a municipal masterplan in force (see Hernández 2015). 
reducing their number by a fourth. The speedy process and the absence of any national/local cooperation $^{16}$ caused many pushbacks from municipalities; and the opportunity for a comprehensive debate on territorial governance was missed, the reform being perceived locally as another round of expenditure cut (see Seixas et al. 2016, 229-230) and a surreptitious recentralization of power (Teles 2016).

In Greece, the Kalikratis Plan (Law 3852/2010), requested by the first memorandum of understanding in name of efficiency and reducing public expenditure (EC 2010, 53), reduced by two thirds the number of territorial polities under a discourse of democratization, convergence toward federal countries and modernization of governance (Chardas 2014). The reform did not change the role of local authorities in spatial planning, which is mostly advisory; and in the case of Athens-Attica, the metropolitan planning governance has been recentralized, abolishing the organization responsible for the implementation of the Athens Master Plan and transferring its responsibilities to the Ministry of Environment and Energy (Asprogerakas 2016).

In Italy, the European Central Bank suggested in 2011, among several reforms, the abolition of provinces. ${ }^{17}$ Law 56/2014 transformed the provinces into covenants of representatives of municipalities and established the metropolitan cities (a process launched in 1990, but never implemented). The reform was brought forward amid claims of reducing public expenditure (an extremely powerful political discourse in Italy) and enhancing

16 Municipalities had 90 days to elaborate a proposal of reorganization. Due to absence of time, most municipalities presented no proposal and, with few exceptions (like Lisbon, which had launched the reform years before), new parishes were designed by a national working group and imposed by law.

${ }^{17}$ Never formally released, the letter, signed by Jean-Claude Trichet and Mario Draghi and dated 5 August, was published by the press. Available at www.voltairenet.org/article171574.html (accessed 30 November 2019). 
subsidiarity (reducing the number of governmental levels and harmonizing multi-level governance). Riboldazzi (2017, 105) emphasized a number of criticalities: the overlap between the territories of, and the imbalances of power between, metropolitan cities and provinces, as well as between the central municipality and other municipalities in a metropolitan region; ${ }^{18}$ and the confusion with regard to the scope of the metropolitan cities' planning instruments.

Finally, though not explicitly requested by European institutions, the Spanish government launched a comprehensive reform of the public administration. The 2011 constitutional reform promoted by a centre-left government, by introducing stricter financial conditionality (art. 135), impacted especially the comunidades autonomas, which are principally responsible for welfare spending (see Marti-Costa and Tomàs 2017, 2117). In 2013, the centre-right Partido Popular, which had been advocating a roll back of regional autonomy, ${ }^{19}$ took power and its 2013 reform of the local administration (Law 27/2013 about 'Rationalization and sustainability of local administration') is a 'clear example of a programme of legal recentralization, which shows the governmental mistrust in autonomy (in this particular case, in local autonomy)' (Palop 2014, 19). Under a discourse of 'streamlining' government, the powers of local governments, as well as the capacity of comunidades autonomas to regulate these latter, were limited (idem) at the same time as improving the chances of private companies to manage local services' (Marti-Costa and Tomàs 2017, 2118; see also Del Pino and Pavolini, 2015). ${ }^{20}$

\footnotetext{
${ }^{18}$ Which, in some cases, like Turin, ended up creating political and administrative impasse (see Caruso, Cotella and Pede 2016).

${ }^{19}$ As declared, for instance, in 2011, by then leader of the party José María Aznar (La Vanguardia 2011).

${ }^{20}$ The reform was warmly welcomed by the OECD (2013).
} 
These complex processes of rescaling were never complemented by increased financial resources for local authorities - quite the opposite. Not only was none of the abovementioned reforms integrated by increased transferences from the state or, for instance, the introduction of new local taxes (see, e.g., Del Pino and Pavolini 2015; Teles 2016). The reforms were also implemented in a context characterized by decreasing incomes for local authorities, both because of the economic crisis and rounds of cuts - for instance, in Italy the municipal property tax was abolished in 2011 amid the economic crisis and right before the crisis of the sovereign debt.

\section{The local against the national/European?}

While the national-level dynamics of change show many degrees of coherence, quite different goals have been prioritized at the local level. Cities of all four countries have been the places where crisis and austerity have been contested and alternatives emerged via public protests against austerity (Accornero and Pinto 2015) and new forms of local organization (Kaika and Karaliotas 2016; García-Lamarca 2017). With more evidence in Spain and Italy, the burgeoning of new political actors, particularly in big cities, ${ }^{21}$ resulted in increasing dialectic between cities and national governments. Some local experiences are trying to scale up their action at the same time as reasserting the centrality of local politics, the most known

${ }^{21}$ See the very different experiences of coalitions between left-wing, centre-left parties and Podemos in Spain (e.g. Barcelona, Madrid, Seville and Valencia), and the cities won by the 5 Stars Movement (e.g. Rome and Turin) and the cities (e.g. Naples, Palermo and Messina) governed by independent left-wing platforms, in some cases loosely united with mainstream centre-left parties, in Italy. 
example being the 'municipalist' network guided by Barcelona en Comu, the coalition governing Barcelona. ${ }^{22}$

Amid this political climate, many cities have been acting in different, when not opposite, directions to those pushed by national reforms, as we shall exemplify with a brief discussion of approaches to public participation and the tourism - real estate nexus. As we shall see, the emerging local trends are everything but linear and, in the variety of existing experiences, there is nothing similar to the coherence of national reforms above discussed. First, in opposition to the way national reforms have been curtailing space for participation in spatial planning, many local governments have been betting on citizens' participation to increase legitimacy of policy and spending (in the context of reduced resources). This was particularly evident in Portugal and Spain, where, for instance, the multiplication of experiments of participatory budgeting has consolidated in the years of the crisis (Dias 2014). Italy has shown an opposite trend and, during the years of the crisis, there has been a halt in the longer tradition of development of participatory instruments (idem).

Second, while all national reforms have paved the way for economic growth based on construction and real estate, only some cities have embraced these strategies, while others have developed attempts at resisting to the national pressures to pursue growth through a new round of urban accumulation. This tension is particularly evident with regard to the nexus tourism - real estate in major cities, as, during the years of austerity, tourism has been central to governments' growth strategies. In the context of the Portuguese success in becoming a 'hip' touristic destination, the local government of Lisbon has fully embraced the potential of tourism and real estate as growth engines, and this has brought about an explosion of housing

22 See International Municipalist Summit 'Fearless Cities', held in Barcelona, on June 2017. http://fearlesscities.com/ (accessed 30 November 2019). 
prices that looks like an unprecedented speculative bubble (see Tulumello 2016; Viera et al. 2016). This is different from the trajectory of cities like Barcelona and Madrid, which had long been successful tourism destination. Here, during the last few years additional pressure over housing markets has been brought about by the momentous growth of short-term rentals eased by so-called 'sharing economy' platforms (see, e.g., Cócola-Gant 2016). But, while during the deepest years of the crisis the centre-right mayors had been working to increase touristic presences without regulating the housing market, the new mayors elected in 2015 and supported by left-wing/Podemos coalitions have put housing at the centre of their agenda $^{23}$ and attempted at regulating holiday rentals - regulation made problematic at the local scale by generally 'Airbnb friendly' national and regional legislations (Encarnación 2016, 38; see also Navarro and Berrozpe 2016).

\section{Conclusions}

This overview of spatial planning and territorial governance reforms in Southern European countries in times of crisis and austerity has shown the existence of an overall coherent institutional drive at the national level, with a central role of European institutions in pushing change. National governments have embraced the EU requests, by reacting to conditionalities attached to funding assistance or going beyond them. In the conclusions, we will, first, reflect

23 See, for instance, Barcelona municipality's website that gather all information regarding housing (http://habitatge.barcelona/en) and the Urbact project 'Intermediation service for people in the process of evictions and occupancies' (http://urbact.eu/intermediation-service-people-process-evictions-and-occupancies) (accessed 30 November 2019). 
on the impacts of these reforms for spatial planning systems; and, then, put forth some steps toward theorization by advancing the hypothesis of a EU spatial planning policy 'by stealth'.

\section{Impacts of spatial planning reforms under austerity}

The new spatial planning laws and territorial governance reforms have a clear impact on the local level. New planning laws have in common the simplification of procedures for landuse change and spatial intervention in exception to regulations, as well as the acceleration of procedures for public works. With regards to planning competences at the local level, the trend was toward increased localism - evident, for instance, in the downgrading of supra-local plans in Portugal - in contradiction with reduced local power, due to the increase of procedures to escape municipal regulations. As exposed by non-governmental environmental organizations and planners, these laws constitute serious threats to spatial planning and environmental legislations in these countries, opening spaces for reinforcing clientelistic policymaking processes, selectivity or particularism - marking a regression in comparison with the pre-crisis period (WWF 2014a; 2014b; Asprogerakas 2016; Mourão and MaratMendes 2016).

With regard to territorial governance reforms, the formal discourse about decentralization was in fact mirrored by a complex, twofold process of state rescaling: recentralization of power on many dimensions of spatial planning versus decentralization not accompanied by the provision of the resources necessary to cope with new competences - while local budgets were cut due to austerity policies. According to Mendes (2016), the 'bottom-up' discourse attached to decentralization reforms in Portugal covered up the simple delegation of 'duties and obligations', without resources. This is in line with long-term trends of restructuring of multilevel government, and particularly the way the reshuffling of administrative 'hard 
containers' has been accompanied by the emergence of new 'soft spaces' for governance (Allmendinger et al. 2015). The new, 'soft' governance arrangements, organized as blurred, horizontal associational networks of public, private and civil society actors, have been criticised for pointing in the direction of a greater autocratic governmentality (Swyngedouw $2000 ; 2005)$. In the post-crisis context, the new configurations may bring along with them further legitimacy and accountability issues in the decision-making processes, with more and more planning related decisions to came into power through legislative acts that do not require any particular form of consultation, and often substantially lack consistency when one examine the broad picture.

Beyond general issues of policy accountability, an effect of the combination of procedures to bypass planning regulations with increased competences at the local level amid shrinking resources is the growing risk that urbanization fees may become, once again, the last resource for local authorities to provide services; hence added stimulus to the creation of further real estate bubbles. Here lies the central contradiction of this round of reforms. Though the role of real estate bubbles in the generation of the crisis has been acknowledged and even mentioned in some memoranda of understanding, virtually all reforms requested by European institutions risk to foster the creation of new bubbles - as particularly evident in Portugal and various Spanish towns (Font and Garcia 2015; Banco de Portugal 2018). This has been faced in very different ways at the local level, and while some cities (expressively, Lisbon) embraced the potential of real estate and construction for growth, others (particularly Spanish cities governed by coalitions led by Podemos) have been looking for alternative paths lately.

\section{A EU spatial planning policy by stealth?}


Reflecting on the role of the EU in the context of crisis and austerity, we have seen how the European Commission has, more or less explicitly, fostered spatial planning and territorial governance reforms, despite not having formal competence in this area - for instance, by including spatial planning reforms among licensing and business environment sections of memoranda of understanding. Through the clauses of conditionality attached to financial assistance in Portugal and Greece, and indirect pressure in Italy, the European Commission has assumed a role as regulator and helmsman, going well beyond the role of coordination and harmonization acknowledged in the Treaties. Even if the formal goal of such requests was that of creating more business friendly environments and enhance growth, the various memoranda of understanding and the exertion of influence of the European Central Bank on the Italian government paint a rather coherent framework. This resonates squarely with Doling's discussion of a European housing policy 'by stealth' (2006). In this case, given the specific spatial focus, one should more appropriately talk of Southern European spatial planning policy by stealth developed by the EU in times of crisis and austerity.

How can we start making sense of the transformations pushed by this policy by stealth, and reactions thereof? First, we have seen how local conditions and national planning traditions have been clashing with external attempts aiming at homogenization, in terms of 'one size fits all' policies in the Southern European countries even if the conditions in these countries differ from each other. In this light, these attempts may - by replicating 'solutions' that were efficient in some contexts but that do not seem to have helped in preventing the generation of the preconditions for the economic crisis - end up aggravating the very problems they intended to solve in the first place. This resonates squarely with recent calls for the need to overcome taxonomic and linear explanations of spatial planning evolution (Getimis 2012; Tulumello et al. 2018). Second, Southern Europe seems to be also a prototypical space where European institutions - in amid austerity politics and with different participation of national 
governments - have been able to test and implement spatial planning and territorial governance reforms. What we have also seen is the risk that these reforms - irrespective of what their original intentions may have been - ultimately end up deepening neoliberal governance (see, e.g., Papageorgiou 2017) and relaunch patterns of uneven territorial development that the global financial crisis had complicated or halted (cf. Hadjimichalis 2011). Hence, third, Southern Europe under crisis and austerity is also a political space where planning and territorial governance are at the core of contestation and conflict, as particularly evident in top-down/bottom-up clashes, but lately, if somehow contradictorily, emerging from changing national politics as well. ${ }^{24}$ Whether the coherent pressures from above or fragmentary responses from below will prevail, and what new hegemonies will emerge from their clash are crucial issues that will define the state of the European political space in the near future.

\section{References}

Accornero, Guia and Pedro R. Pinto. 2015. “'Mild Mannered'? Protest and Mobilisation in Portugal under Austerity, 2010-2013.” West European Politics 38 (3): 491-515.

Akin, Ozlem, José G. Montalvo, Jaume G. Villar, José-Luis Peydró and Josep M. Raya. 2014. “The Real Estate and Credit Bubble: Evidence from Spain. SERIEs 5 (2-3): 223-243.

\footnotetext{
${ }^{24}$ We think of the conflicts between European institutions and the left-wing Greek government during the first months of its tenure (2015); and of the, indeed contradictory, attempts by the centre-left/left-wing coalition governing Portugal since late 2015 at reversing austerity (Jones 2017; Teles 2018).
} 
Allmendinger, Phil, Graham Haughton, Jörg Knieling and Frank Othengrafen, eds. 2015. Soft Spaces in Europe: Re-negotiating Governance, Boundaries and Borders. Abingdon: Routledge.

Arampatzi, Athena. 2017. "The spatiality of counter-austerity politics in Athens, Greece: Emergent 'urban solidarity spaces'.” Urban Studies 54 (9): 2155-2171.

Asprogerakas, Evangelos. 2016. "Strategic Planning and Urban Development in Athens. The Current attempt for Reformation and Future Challenges." Keynote speech at Sustainable Urban Planning and Design Symposium, Nicosia, 13 May.

Banco de Portugal. 2018. Relatório de Estabilidade Financeira. Junho 2018. Accessed 30 November 2019. $\quad$ www.bportugal.pt/sites/default/files/anexos/pdfboletim/ref_06_2018_pt.pdf.

Bauer, Michael W. and Stefan Becker. 2014. "The Unexpected Winner of the Crisis: The European Commission's Strengthened Role in Economic Governance.” Journal of European Integration 36(3): 213-229.

Blyth, Mark. 2013. Austerity. The History of a Dangerous Idea. New York: Oxford University Press.

Böhme, Kai and Bas Waterhout. 2008. "The Europeanization of Planning." In European Spatial Research and Planning, edited by Andreas Faludi, 225-248. Cambridge: Lincoln Institute of Land Policy.

Campos, Vítor and João Ferrão. 2015. “O Ordenamento do Território em Portugal: Uma Perspetiva Genealógica." ICS Working Papers, 2015-1. http://repositorio.ul.pt/handle/10451/20716.

Carballo-Cruz, Francisco. 2011. "Causes and Consequences of the Spanish Economic Crisis. Why the Recovery is Taken so Long?" Panoeconomicus 58 (3): 309-328. 
Carneiro, Anabela, Pedro Portugal and Jose Varejão. 2014. “Catastrophic Job Destruction during the Portuguese Economic Crisis". Journal of Macroeconomics, 39(B): 444-457.

Caruso, Nadia, Giancarlo Cotella and Elena Pede. 2016. "From Crisis to Crisis. Dynamics of Change and Emerging Models of Governance in the Turin Metropolitan Area." In Cities in Crisis. Socio-spatial Impacts of the Economic Crisis in Southern European Cities, edited by Jörg Knieling and Frank Othengrafen, 257-277. Abingdon: Routledge.

CEC (Commission of the European Communities). 1997. The EU Compendium of Spatial Planning Systems and Policies. Luxembourg: Office for Official Publications of the European Communities.

Chardas, Anastassios. 2014. "The Interplay between Austerity, Domestic Territorial Reform and European Union Cohesion Policy: Multi-level Governance and the Application of the Partnership Principle in Greece.” European Urban and Regional Studies 21 (4): 432-444.

Chuliá, Helena, Montserrat Guillen and Miguel Santolino. 2016. "The economic and Financial Crisis: Origins and Consequences.” In Cities in Crisis. Socio-spatial Impacts of the Economic Crisis in Southern European Cities, edited by Jörg Knieling and Frank Othengrafen, 13-26. Abingdon: Routledge.

Cladera, Josep R. and Malcom C. Burns. 2000. "The Liberalization of the Land Market in Spain: The 1998 Reform of Urban Planning Legislation.” European Planning Studies 8 (5): 547-564.

Clauwaert, Stefan and Isabelle Schömann. 2012. "The Crisis and National Labour Law Reforms: A Mapping Exercise.” Working paper 2012/04. Brussels: European Trade 
Union Institute. Accessed 30 November 2019. www.etui.org/Publications2/WorkingPapers/The-crisis-and-national-labour-law-reforms-a-mapping-exercise.

Cócola-Gant, Agustin. 2016. "Holiday Rentals: The New Gentrification Battlefront." Sociological Research Online 21 (3) [online].

Cotella, Giancarlo and Umberto Janin Rivolin. 2011. "Europeanization of Spatial Planning through Discourse and Practice in Italy." disP - The Planning Review 186: 42-53.

Cotella, Giancarlo, Umberto Janin Rivolin and Marco Santangelo. 2015 “Transferring Good Territorial Governance in Europe: Opportunities and Barriers. In Territorial Governance across Europe: Pathways, Practices and Prospects, edited by Peter Schmitt and Lisa Van Well, 238-253. London: Routledge.

Cotella, Giancarlo and Umberto Janin. 2015. "Europeanizazione del Governo del Territorio: Un Modello Analitico.” Territorio 73: 127-134

Cotella, Giancarlo, Frank Othengrafen, Athanasios Papaioannou and Simone Tulumello. 2016. "Socio-spatial and socio-political implications of the economic crisis and austerity politics in Southern-European cities." In Cities in Crisis. Socio-spatial Impacts of the Economic Crisis in Southern European Cities, edited by Jörg Knieling and Frank Othengrafen, 27-47. Abingdon: Routledge.

Del Pino, Eloísa and Emanuele Pavolini. 2015. "Decentralisation at a time of harsh austerity: Multilevel governance and the welfare state in Spain and Italy facing the crisis." European Journal of Social Security 17 (2): 246-270.

Dias, Nelson, ed. 2014. Hope for Democracy. 25 Years of Participatory Budgeting Worldwide. São Bras de Alportel: In Loco.

Doling, John. 2006. “A European Housing Policy?” International Journal of Housing Policy 6 (3): 335-349. 
Donald, Betsy, Amy Glasmeier, Mia Gray and Linda Lobao. 2014. "Austerity in the City: Economic Crisis and Urban Service Decline?" Cambridge Journal of Regions, Economy and Society 7 (1): 3-15.

EC (European Commission). 2010. "The Economic Adjustment Programme for Greece." Occasional Papers 61. https://publications.europa.eu/en/publication-detail//publication/64c89a77-ddc4-46f4-9bb0-18d7e80f6f0c.

EC. 2011a. "The Economic Adjustment Programme for Greece. Fourth review - Spring 2011.” Occasional Papers 82. https://publications.europa.eu/en/publication-detail//publication/0a256be3-f327-4cd6-829a-b797d08365db.

EC. 2011b. "The Economic Adjustment Programme for Portugal." Occasional Papers 79. https://publications.europa.eu/en/publication-detail/-/publication/78853d4f-4bd0-4f8c$\underline{\text { 9f20-462915fa4895. }}$

EC. 2012a. "The Economic Adjustment Programme for Portugal. Fifth review - Summer 2012." Occasional Papers 117. https://publications.europa.eu/en/publication-detail//publication/96d98723-1e59-4173-91d7-646547bf7f64.

EC. 2012b. "The Financial Sector Adjustment Programme for Spain.” Occasional Papers 118. https://publications.europa.eu/en/publication-detail/-/publication/5fc44a97-46ee$\underline{400 f-81 d 2-136 f a 2346 b 1 c}$.

EC. 2012c. "The Second Economic Adjustment Programme for Greece. March 2012." Occasional Papers 94. https://publications.europa.eu/en/publication-detail//publication/aadea5f5-6028-44bc-8707-8d68e2d5b3a3.

Encarnación, Ana M. 2016. "El Alojamiento Colaborativo: Viviendas de Uso Turístico y Plataformas Virtuales.” REALA. Nueva Época 5: 30-55. 
ESPON and Politecnico di Torino. 2014. Towards Better Territorial Governance in Europe. A Guide for Practitioners, Policy and Decision Makers Based on Contributions from the ESPON TANGO Project. Luxembourg: ESPON.

Farinos Dasí, Joaquín, Juan R. González and Inés S. De Madariaga. 2005. "Structural Problems for the Renewal of Planning Styles: The Spanish Case.” European Planning Studies 13 (2): 217-235.

Featherstone, Kevin and Claudio Radaelli, eds. 2003. The Politics of Europeanization. Oxford: Oxford University Press.

Font, Marc and Gemma Garcia. 2015. "Resisting the Next Wave of Real Estate Speculation in Spain.” Roar Magazine, 22 October. Accessed 30 November 2019. https://roarmag.org/essays/spain-evictions-resistance-pah/.

García, Marisol. 2010. "The Breakdown of the Spanish Urban Growth Model: Social and Territorial Effects of the Global Crisis.” International Journal of Urban and Regional Research 34 (4): 967-980.

García-Lamarca, Melissa. 2017. "From Occupying Plazas to Recuperating Housing: Insurgent Practices in Spain.” International Journal of Urban and Regional Research 41 (1): 3753.

Getimis, Panagiotis. 2012. “Comparing Spatial Planning Systems and Planning Cultures in Europe. The Need for a Multiscalar Approach.” Planning Practice and Research 27 (1): $25-40$.

Getimis, Panagiotis, Mario Reimer and Hans H. Blotevogel. 2014. "Conclusion: Multiple Trends of Continuity and Change." In Spatial Planning Systems and Practices in Europe. A Comparative Perspective on Continuity and Changes, edited by Panagiotis Getimis, Mario Reimer and Hans Blotevogel, 278-305. London: Routledge. 
Giannakorou, Georgia. 2005. “Transforming Spatial Planning Policy in Mediterranean Countries: Europeanization and Domestic Change." European Planning Studies 13 (2): 319-331.

Gielen, Demetrio M. and Tuna Tasan-Kok. 2010. "Flexibility in Planning and the Consequences for Public-value Capturing in UK, Spain and the Netherlands." European Planning Studies 18 (7): 1097-1131.

Governa, Francesca and Carlo Salone. 2005. "Italy and European Spatial Policies: Polycentrism, Urban Networks and Local Innovation Practices.” European Planning Studies 13 (2): 265-283.

Governo de Portugal. 2013. Proposta de Lei de Bases da Política de Solos, de Ordenamento do Território e de Urbanismo. Accessed 30 November 2019. http://www.dgterritorio.pt/static/repository/2014-01/2014-01-27163831_b511271f54fe-4d21-9657-24580e9b7023\$\$5D83BE99-238C-4727-83D4712E7C3188A0\$\$69E67E20-4873-4456-AF03-356A70397C87\$\$file\$\$pt\$\$1.pdf.

Hadjimichalis, Costis. 2011. "Uneven Geographical Development and Socio-spatial Justice and Solidarity: European Regions after the 2009 Financial Crisis.” European Urban and Regional Studies 18 (3): 254-274.

Hadjimichalis, Costis. 2014. "Crisis and Land Dispossession in Greece as Part of the Global 'Land Fever'." City 18 (4/5): 502-508.

Harvey, David. 2012. Rebel Cities. From the Right to the City to the Urban Revolution." London: Verso.

Hernández, Rafael C. 2015. "Nulidad Parcial del PGOU 97. Implicaciones de las Sentencias del Tribunar Superior de Justicia y del Tribunal Supremo para la Ciudad de Madrid.” Cuaderno de Investigación Urbanística 100: 15-18. 
Hopkin, Jonathan and Ken Dubin. 2014. "Historical Institutionalism and Policy-making in Hard Times: The Case of Southern European Labour Reforms." Paper presented at the workshop Policy Making under Hard Times: Southern European Countries in a Comparative Perspective, Madrid, 20-21 November.

Janin Rivolin, Umberto. 2008. "Conforming and Performing Planning Systems in Europe: An Unbearable Cohabitation." Planning Practice and Research 23 (2): 167-186.

Janin Rivolin, Umberto. 2017. "Global crisis and the systems of spatial governance and planning: a European comparison.” European Planning Studies 25(6): 994-1012.

Janin Rivolin, Umberto and Giancarlo Cotella. 2013. “A Conceptual Device for Spreading (Good) Territorial Governance in Europe.” In Second ESPON 2013 Scientific Report. Science in support of European Territorial Development and Cohesion, edited by Frank Holstein, Sabine Zillmer and Kai Böhme, 175-179. Luxembourg: ESPON.

Janin Rivolin, Umberto and Andreas Faludi. 2005. “The Hidden Face of European Spatial Planning: Innovations in Governance.” European Planning Studies 13(2): 195-215.

Jones, Owen. 2017. "No Alternative to Austerity? That Lie Has now Been Nailed." The $\begin{array}{lllll}\text { Guardian, } & 24 & \text { August. } & \text { Accessed } & 30\end{array}$ www.theguardian.com/commentisfree/2017/aug/24/austerity-lie-deep-cuts-economyportugal-socialist.

Kaika, Maria and Lazaros Karaliotas. 2016. "The Spatialization of Democratic Politics: Insights from Indignant Squares.” European Urban and Regional Studies 23 (4): 556570.

Knieling, Jörg, Umberto Janin Rivolin, João Seixas and Galya Vladova. 2016. "Crisis and Urban Change. Reflections, Strategies, and Approaches.” In Cities in Crisis. Sociospatial Impacts of the Economic Crisis in Southern European Cities, edited by Jörg Knieling and Frank Othengrafen, 48-70. London: Routledge. 
Knieling, Jörg and Frank Othengrafen, eds. 2016. Cities in Crisis. Socio-spatial Impacts of the Economic Crisis in Southern European Cities. Abingdon: Routledge.

Labrianidis Lois and Nikos Vogiatzis. 2013. "The Mutually Reinforcing Relation between International Migration of Highly Educated Labour Force and Economic Crisis: The Case of Greece." Southeast European and Black Sea Studies 13 (4): 525-551.

La Vanguardia. 2011. “Aznar Apuesta por la Regresión Autonómica para Superar la Crisis.” La Vanguardia, 14 January. Accessed $30 \quad$ November 2019. www.lavanguardia.com/politica/20110114/54102332116/aznar-apuesta-por-laregresion-autonomica-para-superar-la-crisis.html.

Lingua, Valeria and Loris Servillo. 2014. "The Modernization of the Italian Planning System.” In Spatial Planning Systems and Practices in Europe. A Comparative Perspective on Continuity and Changes, edited by Mario Reimer, Panagiotis Getimis and Hans H. Blotevogel, 127-148. London: Routledge.

Magone, José M. 2014. "Portugal Is Not Greece: Policy Responses to the Sovereign Debt Crisis and the Consequences for the Portuguese Political Economy." Perspectives on European Politics and Society 15 (3): 346-360.

Manasse, Paolo and Dimitris Katsikas, eds. 2018. Economic Crisis and Structural Reforms in Southern Europe: Policy Lessons. Abingdon: Routledge.

Martí-Costa, Marc and Mariona Tomàs. 2017. "Urban Governance in Spain: From Democratic Transition to Austerity Policies.” Urban Studies 54 (9): 2107-2122.

Mendes, Luís. 2016. “Arqueologia de uma Descentralização ‘recentralizadora’: Últimas Notas Subversivas sobre a Reforma da Administração Local Portuguesa.” Movimentos Sociais e Dinâmicas Espaciais 5 (2): 252-283. 
Mora, Alfonso A., María C. Romón, Juan L.R. Sanz, L. S. Ganges. 2011. "Perfiles de Una Tragedia: La Crisis Residencial y Urbanística Española.” Papeles de Relaciones Ecosociales y Cambio Global 113: 57-69.

Mourão, Joana and Teresa Marat-Mendes. 2016. “Urban Planning and Territorial Management in Portugal: Antecedents and Impacts of the 2008 Financial and Economic Crisis.” In Cities in Crisis. Socio-spatial Impacts of the Economic Crisis in Southern European Cities, edited by Jörg Knieling and Frank Othengrafen, 157-171. Abingdon: Routledge.

Moury, Catherine and Adam Standring. 2017. “'Going beyond the Troika': Power and Discourse in Portuguese Austerity Politics." European Journal of Political Research 56 (3): 660-679.

Nadin, Vincent and Dominic Stead. 2013. "Opening up the Compendium: An Evaluation of International Comparative Planning Research Methodologies.” European Planning Studies 21 (10): 1542-1561.

Nadin, Vincent et al. 2018. COMPASS - Comparative Analysis of Territorial Governance and Spatial Planning Systems in Europe. Final Report. Version 10/10/2018. Accessed 30 November 2019. www.espon.eu/sites/default/files/attachments/1.\%20COMPASS_Final_Report.pdf.

Navarro, Nicolás A. G. and Tatiana I. Berrozpe. 2016. “Acción Pública y Consumo Colaborativo. Regulación de las Viviendas de Uso Turístico en el Contexto p2p.” Pasos. Revista de Turismo y Patrimonio Cultural 14 (3): 751-768.

OECD (Organisation for Economic Co-operation and Development). 2013. "Spain: From Administrative Reform to Continuous Improvement." OECD Public Governance Reviews. http://dx.doi.org/10.1787/9789264210592-en. 
Oliveira, Carlos and Isabel Breda-Vázquez. 2011. "Territorial Governance in Portugal: Institutional Change or Institutional Resilience?” disP - The Planning Review 186: 6476.

Oliveira, Fernanda P. 2015. “Algumas Questões Relativas aos Programas Enquanto Instrumentos de Gestão Territorial." In O Novo Regime Jurídico dos Instrumentos de Gestão Territorial, edited by João Miranda, Cláudio Monteiro and Mário Vale, 71-92. Coimbra: Almedina.

Olsen, Johan P. 2002. “The Many Faces of Europeanization.” Journal of Common Market Studies 40 (5): 921-952.

Palop, Andrés B. 2014. “Sentido y Orientación de la Ley 27/2013 de Racionalización y Sostenibilidad de la Administración Local: Autonomía Local, Recentralización y Provisión de Servicios Públicos Locales.” REALA. Nueva Época 2 [online].

Papageorgiou, Marilena. 2017. "Spatial Planning in Transition in Greece: A Critical Overview.” European Planning Studies 25 (10): 1818-1833.

Peck, Jamie. 2012. “Austerity Urbanism,” City 16 (6): 626-655.

Perez, Sofia and Manos Matsaganis. 2017. "The Political Economy of Austerity in Southern Europe”. New Political Economy 23 (2): 192-207.

Pinho, Carlos, Carlos Andrade and Maria F. Pinho. 2010. "Regional Growth Transition and the Evolution of Income Disparities in Europe." Urban Public Economics Review 13: 66-103.

Ponzini, Davide. 2016. "Introduction: Crisis and Renewal of Contemporary Urban Planning." European Planning Studies 24 (7): 1237-1245.

Radaelli, Claudio M. 2002. "Policy Transfer in the European Union: Institutional Isomorphism as a Source of Legitimacy." Governance 13 (1):25-43. 
Radaelli, Claudio M. 2004. “Europeanization: Solution or Problem?” European Integration Online Papers 8 (16) [online].

Reis, José and João Rodrigues. 2011. Portugal e a Europa em Crise. Para Acabar com a Economia de Austeridade. Lisbon: Actual.

Riboldazzi, Renzo. 2017. "Local Government Innovation in Italy and its Impact on Urban and Regional Planning with a Focus on the Milanese Context." In Local Government and Urban Governance in Europe, edited by Carlos N. Silva and Ján Buček, 89-109. Switzerland: Springer.

Romero, Juan, Carme Melo and Dolores Brandis. 2016. "The Neoliberal Model of the City in Southern Europe: A Comparative Approach to Valencia and Madrid.” In Cities in Crisis. Socio-spatial Impacts of the Economic Crisis in Southern European Cities, edited by Jörg Knieling and Frank Othengrafen, 73-93. Abingdon: Routledge.

Rullan, Onofre. 1999. "La Nueva Ley del Suelo de 1998 en el Contexto del Neoliberalismo Postmoderno.” Investigaciones Geográficas 22: 5-21.

Sacchi, Stefano. 2015. “Conditionality by Other Means: EU Involvement in Italy's Structural Reforms in the Sovereign Debt Crisis.” Comparative European Politics 13 (1): 77-92. Salzano, Edoardo. 1998. Fondamenti di Urbanistica. Rome: Laterza.

Santos, Ana C, Nuno Teles and Nuno Serra. 2014. "Finança e Habitação em Portugal." Cadernos do Observatório, 2.

Scattoni, Paolo and Enzo Falco. 2011. "Why Italian Planning is Worth Studying." Italian Journal of Planning Practice 1 (1): 4-32.

Seixas, João and Abel Albet, eds. 2012. Urban Governance in Southern Europe. Farnham: Ashgate.

Seixas João, Simone Tulumello, Ana Drago and Susana Corvelo. 2016. "Potentials and Restrictions on the Changing Dynamics of the Political Spaces in the Lisbon 
Metropolitan Area." In Cities in Crisis. Socio-spatial Impacts of the Economic Crisis in Southern European Cities, edited by Jörg Knieling and Frank Othengrafen, 217238. Abingdon: Routledge.

Silva, Carlos N and Ján Bucek. 2014. “Conclusion.” In Fiscal Austerity and Innovation in Local Governance in Europe, edited by Carlos N. Silva and Ján Bucek, 181-186. Farnham: Ashgate.

Stead, Dominic and Giancarlo Cotella. 2011. "Differential Europe: Domestic Actors and Their Role in Shaping Spatial Planning Systems.” disP 47(186): 13-21.

Swyngedouw, Eric. 2000. Authoritarian Governance, Power and the Politics of Rescaling." Environment and Planning D 18 (1): 63-76.

Swyngedouw, Eric. 2005. "Governance Innovation and the Citizen: The Janus Face of Governance-beyond-the-State.” Urban Studies 42 (11): 1991-2006.

Teles, Filipe. 2016. "Local Government and the Bailout: Reform Singularities in Portugal." European Urban and Regional Studies 23 (3): 455-467.

Teles, Nuno. 2018. “The Portuguese Illusion.” Jacobin, 7 February. Accessed 30 November 2019. https://jacobinmag.com/2018/07/portugal-left-bloc-eurozone-austerity-eu.

Triantafyllopoulos, Nikolaos and Thomai Kandyla. 2010. "Buyers' Behaviour and the Housing Bubble in Greece.” Paper presented at the 17th Annual European Real Estate Society Conference, Milan, 23 June. Accessed 30 November 2019. https://eres.architexturez.net/doc/oai-eres-id-eres2010-036.

Tsakalotos, Euclid. 2014. "Contesting Greek Exceptionalism within the European Crisis." Paper presented at Open Economics Seminar (ASOI), Athens, 16 May. Accessed 30 November 2019. www.e-history.eu/files/uploads/Paper___2011.05.16.pdf. 
Tulumello, Simone. 2016. "Reconsidering Neoliberal Urban Planning in Times of Crisis: Urban Regeneration Policy in a 'Dense' Space in Lisbon.” Urban Geography 37 (1): 117-140.

Tulumello, Simone, Ana C. Ferreira, Alessandro Colombo, Caterina Di Giovanni and Marco Allegra. 2018. "Comparative planning and housing studies beyond taxonomy: A genealogy of the Special Programme for Rehousing (Portugal)." Transactions of the Association of European Schools of Planning, 2 (1): 32-46.

Vieira, Ana B., Catarina Botelho, Joana Braga, António B. Guterres, Leonor Duarte, Luisa Gago and Luís Mendes. 2016. “Quem Vai Poder Morar em Lisboa?” Buala, 13 June. Accessed 30 November 2019. www.buala.org/pt/cidade/quem-vai-poder-morar-emlisboa.

Vitoria, Ximena L. 2013. "Revisión y Modificación de los Planes Urbanísticos: A Propósito de la Sentencia del Tribunal Superior de Justicia de Madrid de 11 de Mayo de 2012.” Revista de Administración Pública 190: 227-240.

Vives, Sònia and Onofre Rullan. 2014. "La Apropriación de las Rentas del Suelo en la Ciudad Noliberal Española.” Boletín de la Asociación de Geógrafos Españoles 65: 387-408.

Wollmann, Hellmut. 2014. "Public Services in European Countries: Between Public/Municipal and private Sector provision - and Reverse?" In Fiscal Austerity and Innovation in Local Governance in Europe, edited by Carlos Nunes Silva and Jân Bucek, 49-76. Farnham: Ashgate.

WWF (World Wildlife Fund). 2014a. "Environmental Legislation in Greece.10th Annual Review - Summary.” Accessed 30 November 2019. www.wwf.gr/crisis-watch/crisiswatch/governance/7-issue-20-november-

2013/download/1_9e5e18a8fd7e37d681b63c3d751c811d. 
WWF. 2014b. "Sblocca Italia, una Manovra contro l'Ambiente. Press release 6 November." Accessed 30 November 2019. www.wwf.it/?11760. 